\title{
COVID-19'da Kronik Hastalıkların Rolü, Önemi ve Öneriler
}

\section{The Role and Importance of Chronic Diseases in COVID-19 and Related Recommendations}

\author{
Beste SANDALCI'(IID), Og̃uz Abdullah UYAROG̃LU²(iD), Gülay SAIN GÜVEN²(IiD) \\ ${ }^{1}$ Hacettepe Üniversitesi Tıp Fakültesi, Iç Hastalıkları Anabilim Dall, Ankara, Türkiye \\ ${ }^{2}$ Hacettepe Üniversitesi Tıp Fakültesi, İç Hastalıkıarı Anabilim Dalı, Genel Dahiliye Bilim Dalı, Ankara, Türkiye
}

Makale atıfi: Sandalcı B, Uyaroğlu OA, Sain Güven G. COVID-19'da kronik hastalıkların rolü, önemi ve öneriler. FLORA 2020;25(2):132-8.

\begin{abstract}
ÖZ
Aralık 2019'da Çin'in Wuhan şehrinde nedeni bilinmeyen viral pnömoni olgularının bildirilmesi üzerine yapılan araştırmalarda etken olarak yeni bir koronavirüs saptanmış olup, SARS-CoV-2 adıverilen virüsün yaptığı hastalı̆ga "Koronavirüs Hastalığı 2019 (COVID19)" adı verilmiştir. Kronik hastalıklar tüm dünyada, COVID-19 salgınında olgu fatalite oranlarını arttıran risk faktörleri arasında birinci sırada yer almaktadır. Kronik hastalıklar, yavaş ilerleyen, üç ay ve daha uzun süreli, birden fazla risk faktörünün neden olduğu, genellikle komplike bir seyir gösteren ve kişinin yaşam kalitesini etkileyen hastalıklardır. Esasında, kronik hastalıklar sessiz bir küresel salgın oluşturmuş, COVID-19 salgını ile beraber salgının etkilerini arttıran bir zemin hazırlamıştır. COVID-19'a ait ilk veriler hastalığın klinik karakteristiği hakkında bilgilerimizi arttırmış olup kronik hastalığı olan bireylerde hastalığın daha sık görüldüğü ve daha ağır seyrettiğine dikkat çekmiştir. Bu yazıda COVID-19 seyrinde ve mortalitesinde önemli bir yer tutan ve en sık görülen kronik hastalıklar ile ilgili literatür bilgisine yer verilmiştir.
\end{abstract}

Anahtar Kelimeler: COVID-19; SARS-CoV-2; Kronik hastalıklar; Hipertansiyon; Diabetes mellitus; Kardiyovasküler hastalıklar; Kronik obstrüktif akciğer hastalığı

\section{ABSTRACT}

\section{The Role and Importance of Chronic Diseases in COVID-19 and Related Recommendations}

$$
\text { Beste SANDALCI', Og̃uz Abdullah UYAROG̃LU², Gülay SAIN GÜVEN² }
$$

\footnotetext{
${ }^{1}$ Department of Internal Medicine, Faculty of Medicine, University of Hacettepe, Ankara, Turkey

${ }^{2}$ Division of General Internal Medicine, Department of Internal Medicine, Faculty of Medicine, University of Hacettepe, Ankara, Turkey
}

In December 2019, a new coronavirus identified, named SARS-CoV-2, as a factor in the investigations conducted on the reporting of viral pneumonia cases in the Wuhan city of China, and the disease called "Coronavirus Disease 2019 (COVID-19)". Chronic diseases take the first line among the risk factors that increase the case fatality rates in COVID-19 outbreak worldwide. Chronic diseases that progress slowly, last for three months or more, caused by over one risk factor, usually show a complicated course and affect the quality of life of the person. In fact, chronic diseases caused a silent global epidemic, and together with the COVID-19 pandemic, they prepared a

Geliș Tarihi/Received: 29/05/2020 - Kabul Ediliș Tarihi/Accepted: 01/06/2020 
ground that increased the effects of the pandemic. The first data of COVID-19 increased our knowledge about the clinical characteristics of the disease and pointed out that the disease is more frequent and more severe in individuals with chronic disease. In this article, the literature information on the most common chronic diseases, with important role in COVID-19 course and mortality, is given.

Key Words: COVID-19; SARS-CoV-2; Chronic diseases; Hypertension; Diabetes mellitus; Cardiovascular diseases; Chronic obstructive pulmonary disease

\section{GiRis}

Aralk 2019'da Cin'in Wuhan sehrinde nedeni bilinmeyen viral pnömoni olgularını bildirilmesi üzerine yapilan araștırmalarda, yeni bir koronavirüs etkeni saptanmıstır. Bașlangıçta "2019-nCoV" adı verilen virüs, daha sonra, "Severe Acute Respiratory Syndrome (SARS)" virüsüne benzerliği sebebiyle "SARS-CoV-2" olarak isimlendirilmistir. Hastallk hızla tüm dünyaya yayılmıs ve 2020 Mart ayında Dünya Sağllk Örgütü (DSÖ) tarafından pandemi olarak ilan edilmiștir. Asemptomatik olgulardan, yoğun bakım izlemi gerektiren akut siddetli solunum yetmezliği ile sonuçlanan olgulara kadar genis bir klinik spektrumda ortaya çkan "Koronavirüs Hastalığ1 2019 (COVID-19)", 12 Mayıs 2020 itibariyle dört milyondan fazla kișiyi infekte etmiș ve üc yüz bine yakın insanın ölümüne neden olmustur ${ }^{[1]}$.

COVID-19'a ait ilk veriler hastalığın klinik özellikleri hakkında bilgilerimizi artırmıștır. Cin'de 1099 hasta ile yapilan, cok merkezli, epidemiyolojik bir calıșmada median yașın 47 olduğu, hastalığın \%52.1 ile erkeklerde daha sı görüldüğü ve hastaların \%23.7'sinde eșlik eden en az bir kronik hastalı [hipertansiyon (HT), diyabet (DM), kronik obstrüktif akciğer hastalığı (KOAH) gibi] bulunduğu saptanmıștır. Aynı calıșmada hastaların \%2.3'üne invaziv mekanik ventilasyon gerektiği, \%5.1'inin yoğun bakım ihtiyacı olduğu ve \%1.4'ünün öldüğu bildirilmiștir ${ }^{[2]}$. Tüm hastalar içinde mekanik ventilasyon gereksinimi, yoğun bakım ihtiyacı ve ölüm olarak belirlenen sonlanım noktası kümülatif riski \%3.6 iken, siddetli hastalıkta kümülatif riskin \%20.6'ya kadar yükseldiği görülmüștür ${ }^{[2]}$. Wuhan'da yapilan bir bașka calıșmada SARS-CoV-2 ile infekte 52 yoğun bakım servisi hastasında mortalite \%61.5 olarak bildirilmistir. Bu hastaların \%67'sinde akut solunum skkıntısı sendromu (ARDS), \%29'unda akut böbrek hasarı, \%29'unda akut karaciğer disfonksiyonu geliștiği görülmüștürr ${ }^{[3]}$. Nisan 2020'de yayınlanan, 3062 COVID-19 hastasının klinik özelliklerinin incelendiği bir meta-analizde ise hastalığın fatalite oranı \%5.5 (\%95 GA) olarak saptanmıștır ${ }^{[4]}$.
Kronik hastalıklar, yavas ilerleyen, üc ay ve daha uzun süreli, birden fazla risk faktörünün neden olduğu, genellikle komplike bir seyir gösteren ve kișinin yașam kalitesini etkileyen hastalıklardır. COVID-19 salgınında olgu fatalite oranlarını arttıran risk faktörleri olan bu hastalıklar tüm dünyada, gelișmiș veya gelișmekte olan ülkelerin tümünde, ölüm nedenlerinin bașında gelmistiri ${ }^{[5]}$. Esasında kronik hastalıklar sessiz bir küresel salgin olușturmus, COVID-19 salgını ile beraber salgının etkilerini arttıran bir zemin hazırlamıstır.

Erken dönemde elde edilen veriler, kronik hastalığı olan bireylerde hastalığın daha sık görüldüğüne ve daha ağır seyrettiğine dikkat cekmisțir. Ocak 2020'de Wuhan'dan yayınlanan bir calıșmada, 99 hastanın \%51'inde en az bir kronik hastalık varlığı tespit edilmiş olup, bu hastalıkların coğunluğunu kardiyovasküler hastalıklar $(\mathrm{KVH})$, serebrovasküler hastallklar (SVH) ve DM'nin olușturduğu tespit edilmistiri $^{[6]}$. Benzer sekilde Cin'de yapilan retrospektif, cok merkezli bir kohort calısmasında hastaların \%48'inde komorbiditelerin eșlik ettiği, bu hastaların en sık HT (\%30) olmak üzere DM (\%19) ve koroner arter hastalığ $(\mathrm{KAH})$ 'na (\%8) sahip oldukları gösterilmistirir ${ }^{[7]}$. COVID-19 tanisı ile yatan 813 hastanın dahil edildiği bu kohort calıșmasında, hastane içi ölüm oranının DM (OR 2.85) ve $\mathrm{KAH}$ (OR 21.4) olanlarda daha yüksek olduğu raporlanmistur ${ }^{[7]}$.

Veriler arttıkça kronik hastalıklar ile COVID-19 arasındaki ilișki daha da netleșmiștir. Yakın zamanda yayınlanan, 1139 COVID-19 hastası ile 11.390 sağlıklı popülasyonun karșılaștırıldığı bir calıșmada, olgulardaki $\mathrm{KVH}(\mathrm{OR} 1.98)$ ve $\mathrm{KVH}$ risk faktörlerinin (OR 1.46) kontrol grubuna göre yüksek olduğu, ayrica olgularda HT (OR 1.27), KOAH (OR 1.35), DM (OR 1.5), kalp yetmezliği (KY) (OR 2.18) gibi komorbid hastalıkların popülasyon kontrolüne göre daha sık bulunduğu gösterilmiștir ${ }^{[8]}$.

$\mathrm{Bu}$ yazıda, COVID-19 seyrinde ve mortalitesinde önemli bir yer tutan ve en sik görülen kronik hastalıklar ile ilgili literatür bilgisine yer verilmiștir. 


\section{DIABETES MELLITUS}

COVID-19 hastalığına en sık eșlik eden, hastalığın seyri ve mortalitesini etkilediği görülen kronik hastalıklardan biri tip 2 DM olarak saptanmıștır.

DM prevalansının \%10.9 olduğu Çin'de, Hastalı Kontrol ve Önleme Merkezi [Centers for Disease Control and Prevention (CDC)] tarafindan 20.982 hastanın araștıııldığı calıșmada \%5 hastada DM saptanmıștır ${ }^{[9]}$. İtalya'da ciddi seyirli 1591 COVID-19 hastası ile yapilan bir calıșmada DM olanların sayısı 180 (\%17) idi ${ }^{[10]}$. New York'ta 393 hasta ile yapilan retrospektif bir olgu serisinde hastaların \%25.2'sinde DM'nin eșlik ettiği görülmüsțür ${ }^{[11]}$.

Cin'de 7337 COVID-19 hastasının dahil edildiği retrospektif, cok merkezli bir kohort calıșmasında DM hastalarında diyabetik olmayan gruba göre yorgunluk ve dispnenin daha cok olduğu, eslik eden kronik hastalıkların ve mekanik ventilasyon ihtiyacının daha sık olduğu, 28 günlük takibin sonunda hastane içi ölüm oranının istatistiksel olarak anlamlı sekilde daha yüksek olduğu gösterilmiștir ${ }^{[12]}$. Yine bu hastalarda COVID-19 hastalığ1 için kötü prognoz kriterleri olarak kabul edilen lenfosit sayısında azalma, nötrofil sayısında artıs, C-reaktif protein (CRP) yüksekliği ve interlökin (IL)-6 artıș saptanmıștır [12]. SARS-CoV-2 infeksiyonu ve kronik komorbid hastalıkların iliskisinin incelendiği ve 34 makaleyi kapsayan bir meta-analizde diyabetik hastaların DM olmayanlara göre siddetli hastalık gecirme risklerinin 2.61 kat fazla olduğu bulunmuștur ${ }^{[13]}$.

Kulcsar ve arkadașları tarafından olușturulan bir fare modelinde, insan dipeptidil peptidaz-4 (DPP4) ekspresyonu ile fareler, "Middle East Respiratory Syndrome-Coronavirus (MERS-CoV)" için duyarlı hale getirilmiş ve yüksek yağlı diyet ile tip $2 \mathrm{DM}$ indüklenmiștir. Bu calıșmada diyabetik farelerin daha az inflamatuvar monosit/makrofaj ve sitokine sahip olduğu gösterilmis, bu durumun MERS hastalarında immün yanıtın bozulmasına, sonuc olarak uzamıs ve siddetli akciğer patolojisine neden olduğu gösterilmiștir ${ }^{[14]}$.

Diyabetik hastaların solunum yollarında meydana gelen mikroanjiyopatik değisiklikler, gaz değisimi ve akciğer kompliyansını azaltmakta ve FVC ile $\mathrm{FEV}_{1}$ 'de belirgin azalmaya neden olmak- tadir $^{[15]}$. Mevsimsel influenza boyunca diyabetik hastaların sağllklı gruba göre ciddi hastalık geçirme ve hospitalizasyon risklerinin altı kat, pnömoni komplikasyonları nedeniyle ölüm risklerinin üc kat fazla olduğu bilinmektedir ${ }^{[16]}$. Benzer sekilde SARS ve MERS epidemilerinde de diyabet, kötü prognozla iliskili birkac risk faktöründen biri olarak görülmüstürur ${ }^{[17]}$.

SARS-CoV-2 ile infekte olan DM hastaları, ileri yas, diğer komorbiditeler ve kötü glisemik kontrolün eșlik etmesi durumunda mutlaka hastaneye yatırılarak yakın takip edilmelidir. Özellikle yoğun bakım ihtiyacı olan ciddi seyirli hastalık durumunda metabolik asidoz ile iliskili metformin ve dehidratasyona neden olabilen sodyum glukoz ko-transporter-2 inhibitörleri kesilmeli, insülin, kan sekeri regülasyonunda tercih edilecek ajan olmal1dir. SARS-CoV-2'nin MERS-CoV gibi insan DPP4 reseptörüne tutunduğu düsünüulmekte olup bu konuda araștırmalar devam etmektedir ${ }^{[18]}$.

\section{HIPERTANSIYYON}

Hipertansiyon (HT), COVID-19 ile ilgili yayınlanan pek cok epidemiyolojik calıșmada en sık eslik eden komorbidite olarak yer almaktadır. HT'nin eșlik ettiği COVID-19 hastalarında mortalite ve morbiditenin arttığı, Çin kaynaklı pek cok gözlemsel calıșmada ortaya konulmustur ${ }^{[19]}$.

Cin'de 25 hastaneden 1004 COVID-19 süpheli hastanın incelendiği gözlemsel bir kohort calışmasında, COVID-19 tanısı konulan 188 hastanın \%12'sinde HT olduğu görülürken, tanı konulmayan 816 hastada bu oran \%7 olarak saptanmıștır [20]. Amerika Birlesik Devletleri (ABD)'nde yapilan bir çalıșmada, 14 eyalette COVID-19 nedeniyle hastaneye yatırılan 1482 hastanın \%89.3'ünde en az bir kronik hastalık varken, \%49.7 sıklık ile HT ilk sırada yer almıstırir ${ }^{[21]} 1352$ hastayı kapsayan dört olgu kontrol calıșmasının meta-analizinde HT en sik eslik eden komorbidite olarak bulunmus ve HT'nin eslik ettiği olgularda yoğun bakım basvuru riskinin arttığı (OR 2.54) raporlanmıștır ${ }^{22]}$. COVID-19 hastalarında ARDS ve ölüm risk faktörlerinin incelendiği ve 201 hastanın yer aldığı retrospektif bir kohort çalıșmasında, ARDS gelisen hastaların \%27.4'ünde HT saptanırken, ARDS gelismeyenlerde bu oran \%13.7 olarak tespit edilmiş, ancak istatistiksel olarak anlamlı 
fark gösterilememiștir ${ }^{[23]}$. Cin'de 1590 COVID-19 hastasında kronik hastalıkların etkisini inceleyen cok merkezli bir calısmada HT olan hastalarda (\%10.4), HT olmayanlara göre (\%1.7) mortalite daha yüksek tespit edilmiștir ${ }^{[24]}$.

SARS-CoV'da olduğu gibi SARS-CoV-2 de, hedef hücrelere akciğer, böbrek, kan damarları epitelyal hücreleri üzerinde eksprese edilen anjiyotensin dönüștürücü enzim 2 (ACE2)'ye bağlanarak girer. ACE inhibitörü veya reseptör blokeri ile tedavi edilen HT ve DM hastalarında ACE2 ekspresyonu $\operatorname{artar}^{[25]}$. Bu potansiyel up-regülasyonun virüsün konak hücrelere giris yolunu arttırarak COVID-19 riskini arttırması fikri pek cok yazar tarafından gündeme getirilmiștir. Öte yandan ACE2'nin anjiyotensin 2'den anjiyotensin 1-7 olusturmas1, bu yolla meydana gelen vazodilatör etkinin viral pnömonide akciğer hasarını azaltabileceği birkac hayvan deneyinde gösterilmistirir ${ }^{[19]}$. Benzer sekilde SARS-CoV-2 spike (S) protein tarafından down-regüle edilen ACE2'nin, renin anjiyotensin aldosteron sistemi (RAAS) blokajı ile arttrilabileceği, böylece SARS-CoV-2'nin etkilerinin antagonize edilebileceğini savunan görüssler de öne sürülmüstür ${ }^{[26]}$. Anjiyotensin reseptör blokeri (ARB) ile tedavi edilen hastalarda miyozit üzerindeki ACE2 aktivasyonunun azaldığını gösteren post-mortem çalıșmalarda celișkili bilgiler ortaya sürülmüștür ${ }^{[27]}$. Amerikan Kalp Derneği ve Amerikan Kardiyoloji Koleji (AHA/ACC) yayınladıkları ortak bir bildiriyle $\mathrm{KY}$, iskemik kalp hastalığı ve HT gibi hastalıklarda yararlı olduğu kanıtlanmıs RAAS antagonistlerinin COVID-19 hastalarında devam edilmesini önermislerdir ${ }^{[28]}$. Madrid'den yayınlanan bir olgu popülasyon calıșmasında RAAS inhibitörü kullanan hastalarda COVID-19 nedeniyle hastane yatıs riskinde artıs olmadığı, uzun ve kısa dönem ilaç kullanmak arasında da anlamlı fark olmadığı gösterilmiștir. $\mathrm{Bu}$ çalıșmanın önemli bulgularından biri ise RAAS inhibitörü kullanan DM hastalarında COVID-19 nedeniyle hastane yatıs riskinin daha az bulunmasıdır (OR 0.53, $\mathrm{p}=0.004)^{[8]}$.

HT'nin eșlik ettiği COVID-19 hastaları, mekanik ventilatör ihtiyacı ve yoğun bakım gereksinimi açısından dikkatle izlenmelidir. Uzun süreyle HT tanisı olan ve hedef organ hasarı bulunan hastaların ileri yașam desteği sağlayan hastanelere transferi hızlıca sağlanmalıdır. RAAS inhibitörleri ile tedavi edilen hastalarda infeksiyonun seyri ve bu ilaçların COVID-19 yönetimindeki yeri ileride pek çok pre-klinik ve klinik çalıșmada konu edilecek olup tartıșmalar devam etmektedir.

\section{KARDIYOVASKÜLER HASTALIKLAR}

COVID-19 hastalarında, eșlik eden komorbiditeler içerisinde DM ve HT'ye göre sıklğg daha düsüuk olsa da, KVH'lerin infeksiyonun seyri ve mortalitesinde belirleyici olduğu yapılan calıșmalarda ortaya konmustur.

Cin'de 575 hastaneden 1590 olgunun dahil edildiği retrospektif bir çalıșmada hastaların \%3.7'sinde $\mathrm{KVH}$ olduğu tespit edilmiștir[29]. ABD'de olguların \%30'dan fazlasının görüldüğü New York'ta hastanede yatan 5700 COVID-19 hastasiyla yapilan calışmada 595 (\%11.1) hastada KAH ve 371 (\%6.9) hastada konjestif $\mathrm{KY}$ görülmüștür ${ }^{[30]}$

Wang ve arkadașları tarafından yapılan meta-analizde, $\mathrm{KVH}$ olanlarda ciddi hastalık riskinin 3-4 kat fazla olduğu bulunmuștur ${ }^{[13]}$. Benzer sekilde 1527 SARS-CoV-2 ile infekte hastanın dahil edildiği bir meta-analizde yoğun bakım ihtiyacı olanlarda $\mathrm{KVH}(\mathrm{RR}=3.30$, \%95 GA) rölatif riskinin yoğun bakım izlemi gerektirmeyenlere göre daha yüksek olduğu saptanmıștır ${ }^{[31]}$. Washington eyaletinde ciddi seyirli COVID-19 hastaları ile yapilan bir calıșmada, daha önce bilinen sol ventrikül disfonksiyonu olmayan hastalarda da akut KY gelișebileceği belirtilmiștir. Pulmoner tutulumu belirgin olmayan hastalarda dahi kardiyomiyopatinin geliștiği gözlemlenmiștir ${ }^{[32]}$.

COVID-19 hastalarında daha cok solunum semptomları ön planda gibi görülse de ciddi kardiyak hasar oluștuğu ve altta yatan $\mathrm{KVH}$ durumunda ölüm riskinin arttığı gösterilmiștir ${ }^{[33]}$. Wuhan'da SARS-CoV-2 nedeniyle ölen 168 hastanın dahil edildiği cok merkezli bir calıșmada hastaların \%74.4'üne en az bir kronik hastalığın eșlik ettiği, \%18.5'inde iskemik kalp hastalığı olduğu görülmüștür ${ }^{[34]}$. Cin Hubei'de asemptomatik olguların da dahil edildiği 44.672 COVID-19 hastasından elde edilen verilere göre komorbid hastalığı olmayanlarda fatalite oranı \%0.9 iken $\mathrm{KVH}$ olanlarda bu oran \%10.5'e kadar clkmaktadır ${ }^{[35] .}$

COVID-19'da hastalık siddeti ve mortalite ile ilișkili olarak troponin seviyesinde artıș olduğu bi- 
linmekte olup siddetli viral infeksiyonlar "Systemic Inflammatory Response Syndrome (SIRS)"a neden olarak plak rüptür ve trombüs formasyon riskini arttırmaktadır $^{[36]}$. COVID-19 hastalarında kardiyovasküler olayların etkisini araștıran bir calıșmada, altta yatan $\mathrm{KVH}$ bulunanlarda troponin yüksekliğinin daha sık izlendiği (\%13.2-54.5) ve yüksek troponin seviyesi olanlarda ARDS, malign aritmi ve akut böbrek hasarı gibi komplikasyonların daha sık görüldüğui sonucuna varılmıștır ${ }^{[37]}$. SARS-CoV2'nin primer olarak kalpte perisitlere saldırdığını gösteren calıșmalar, bu yolla olușan kapiller endotelyal hücre disfonksiyonunu ve kardiyak hasar belirteçlerindeki artıșı açıklayabilir ${ }^{[27]}$.

SARS-CoV-2 ile infekte hastalarda $\mathrm{KVH}$ bulunması kötü prognostik bir faktör olarak öne çıkmaktadır. Ciddi seyirli hastalığı olanlarda yeni gelișen KY ve akut iskemik kalp hastalıklarının da olabileceği akılda tutulmalıdır.

\section{KRONIK OBSTRÜKTIF AKCIĞER HASTALIĞI}

Kronik obstrüktif akciğer hastalığı (KOAH) alevlenmesinde viral solunum yolu infeksiyonlar1nın rol oynadığı bilinse de literatürde genel popülasyon ile karșılaștırıldığında $\mathrm{KOAH}$ hastalarının SARS-CoV-2 ile hastane bașvuru sıklığında artıșa rastlanmamıstır [38].

Çin'de SARS-CoV-2 ile infekte hastaların klinik özelliklerini inceleyen sistematik bir derlemede, kronik akciğer hastalığı oranı $\% 0.0$ ile \%17.0 (median \%2) arasında saptanmıstır [39]. Yașlı ve orta yașlı COVID-19 hasta gruplarının karșılaștırıldığı tanımlayıcı bir calıșmada 80 yas ve üzerinde $\mathrm{KOAH}$ daha yuiksek oranda bulunmustur ${ }^{[40]}$.

Çin'de komorbid hastalıkların etkilerinin incelendiŏi çok merkezli bir çalıșmada yas ve sigara içme durumu düzeltildiğinde $\mathrm{KOAH}$ hazard oranı 2.68 (\%95 GA) olarak bulunmustur ${ }^{[24]}$. On bir olgu serisinin incelendiği, 2002 hastayı kapsayan sistematik bir derlemede ise KOAH'ın eșlik ettiği COVID-19 hastalarında siddetli hastalık riskinin dört katına çıtığı (OR 4.38) ve aktif sigara içenlerde bu riskin yaklașık iki katına cıktığı gösterilmiștir (OR 1.98) ${ }^{[41]}$. Aynı calıșmada KOAH'lı hastalarda mekanik ventilasyon ile yoğun bakım ihtiyacının ve mortalitenin istatistiksel olarak an- lamlı sekilde daha yüksek olduğu saptanmıștır (OR 6.44).

Avrupa'da en fazla yașlı popülasyona sahip olan ve pandeminin en cok etkilediği ülkelerden biri olan İtalya'da, SARS-CoV-2 infeksiyonu ile ölenlerin ortalama yașı 80 iken, yoğun bakım desteği gerekenlerde ortalama yas 67 olarak bulunmuștur. Bu durum İtalya'nın yașlı popülasyonunda sigara içen sayısının cokluğu ve $\mathrm{KOAH}$ veya iskemik kalp hastalığına sahip hastaların yuiksek oranda olmasıyla ilișkilendirilmiștir [42]

Kanada'da yapilan preklinik bir calıșmada, solunum epitelyal hücrelerinde $\alpha 7-n A C h R$ kodlayan CHRNA7 ekspresyonunun, bu hücrelerde ACE2 ekspresyonu ile belirgin sekilde ilișkili olduğu gösterilmistir. KOAH hastalarında CHRNA7 ekspresyonunun $\mathrm{KOAH}$ olmayanlara göre daha fazla olduğu ve sigara içenlerde artma eğiliminde olduğu tespit

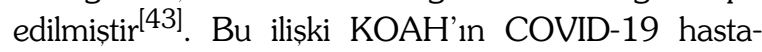
larında artan morbiditeye olan etkisini açılayabilir.

Her ne kadar $\mathrm{KOAH}$, artmıs infeksiyon riski ile ilișkilendirilmese de bu hastalarda ileri yas ve eșlik eden KVH sıklığının fazla olduğu unutulmamalıdır. Pandemi döneminde viral bulașın en aza indirilmesi için hastalarda nebülizatör kullanımından kaçınılmalı ve inhaler tedavi tercih edilmelidir. $\mathrm{KOAH}$ hastalarında inhaler steroid kullanımının COVID-19 seyri üzerindeki etkisi araștırılmaya devam etmekte olan bir bașlık olarak önemini korumaktadir.

\section{SONUÇ}

Simdiye kadar SARS-CoV-2 ilișkili viral pnömoni tedavisinde etkin ilaç ve așı geliștirilememiștir. Kronik hastalıkların varlığı SARS-CoV-2 ile infekte olma riskini arttırdığı gibi, infekte hastalarda da hastalığın seyrini önemli derecede etkileyerek yoğun bakım ihtiyacının artmasına neden olmakta ve mortaliteyi arttırmaktadır. Kronik hastalıkların yakın takibi ve kontrol altına alınması COVID-19 hastalık seyrini olumlu yönde değiștirebileceği gibi, sağlık sektöründeki kısıtlı kaynakların doğru kullanılmasını da mümkün hale getirecektir.

\section{ÇIKAR ÇATIŞMASI}

Yazarlar bu makale ile ilgili herhangi bir çkar catıșması bildirmemișlerdir. 


\section{KAYNAKLAR}

1. COVID-19 Dashboard by the Center for Systems Science and Engineering (CSSE) at Johns Hopkins University (JHU) [Available from: https://coronavirus.jhu.edu/map.html.

2. Guan WJ, Ni ZY, Hu Y, Liang WH, Ou CQ, He JX, et al. Clinical characteristics of coronavirus disease 2019 in China. N Engl J Med 2020;382(18):1708-20.

3. Yang $X, Y u Y, X u$ J, Shu $H$, Xia J, Liu $H$, et al. Clinical course and outcomes of critically ill patients with SARS-CoV-2 pneumonia in Wuhan, China: a single-centered, retrospective, observational study. Lancet Respir Med 2020;8(5):475-81.

4. Zhu J, Ji P, Pang J, Zhong Z, Li H, He C, et al. Clinical characteristics of 3,062 COVID-19 patients: a meta-analysis. J Med Virol 2020.

5. Organization WH. Noncommunicable diseases [Available from: https://www.who.int/news-room/fact-sheets/detail/ noncommunicable-diseases.

6. Chen N, Zhou M, Dong X, Qu J, Gong F, Han Y, et al. Epidemiological and clinical characteristics of 99 cases of 2019 novel coronavirus pneumonia in Wuhan, China: a descriptive study. Lancet 2020;395(10223):507-13.

7. Zhou F, Yu T, Du R, Fan G, Liu Y, Liu Z, et al. Clinical course and risk factors for mortality of adult inpatients with $\mathrm{CO}$ VID-19 in Wuhan, China: a retrospective cohort study. Lancet 2020;395(10229):1054-62.

8. de Abajo FJ, Rodriguez-Martin S, Lerma V, Mejia-Abril G, Aguilar M, Garcia-Luque A, et al. Use of renin-angiotensin-aldosterone system inhibitors and risk of COVID-19 requiring admission to hospital: a case-population study. Lancet 2020;395(10238):1705-14.

9. Singh AK, Gupta R, Ghosh A, Misra A. Diabetes in COVID-19: prevalence, pathophysiology, prognosis and practical considerations. Diabetes Metab Syndr 2020;14(4):303-10.

10. Grasselli $G$, Zangrillo A, Zanella A, Antonelli M, Cabrini L, Castelli $A$, et al. Baseline characteristics and outcomes of 1591 patients infected with SARS-CoV-2 admitted to ICUs of the Lombardy Region, Italy. JAMA 2020;323(16):1574-81.

11. Goyal P, Choi JJ, Pinheiro LC, Schenck EJ, Chen R, Jabri A, et al. Clinical characteristics of Covid-19 in New York city. $N$ Engl I Med 2020.

12. Zhu L, She ZG, Cheng X, Qin JJ, Zhang XJ, Cai J, et al. Association of blood glucose control and outcomes in patients with COVID-19 and pre-existing type 2 diabetes. Cell Metabolism 2020.

13. Wang X, Fang X, Cai Z, Wu X, Gao X, Min J, et al. Comorbid chronic diseases and acute organ injuries are strongly correlated with disease severity and mortality among $\mathrm{CO}$ VID-19 patients: a systemic review and meta-analysis. Research (Wash DC) 2020;2020:2402961.

14. Kulcsar KA, Coleman CM, Beck SE, Frieman MB. Comorbid diabetes results in immune dysregulation and enhanced disease severity following MERS-CoV infection. JCI Insight 2019;4(20):e131774.

15. Hussain A, Bhowmik B, do Vale Moreira NC. COVID-19 and diabetes: knowledge in progress. Diabetes Res Clin Pract 2020;162:108142.
16. Badawi A, Ryoo SG. Prevalence of diabetes in the 2009 influenza A (H1N1) and the Middle East respiratory syndrome coronavirus: a systematic review and meta-analysis. I Public Health Res 2016;5(3):733.

17. de Wit E, van Doremalen N, Falzarano D, Munster VJ. SARS and MERS: recent insights into emerging coronaviruses. Nat Rev Microbiol 2016;14(8):523-34.

18. Gentile S, Strollo F, Ceriello A. COVID-19 infection in Italian people with diabetes: Lessons learned for our future (an experience to be used). Diabetes Res Clin Pract 2020;162:108137.

19. Patel $A B$, Verma A. COVID-19 and angiotensin-converting enzyme inhibitors and angiotensin receptor blockers: what is the evidence? JAMA 2020.

20. Mao B, Liu Y, Chai YH, Jin XY, Lu HW, Yang JW, et al. Assessing risk factors for SARS-CoV-2 infection in patients presenting with symptoms in Shanghai, China: a multicentre, observational cohort study. The Lancet Digital Health.

21. Garg S, Kim L, Whitaker M, O'Halloran A, Cummings C, Holstein $R$, et al. Hospitalization rates and characteristics of patients hospitalized with laboratory-confirmed coronavirus disease 2019 - COVID-NET, 14 States, March 1-30, 2020. MMWR Morb Mortal Wkly Rep 2020;69(15):45864.

22. Roncon L, Zuin M, Zuliani G, Rigatelli G. Patients with arterial hypertension and COVID-19 are at higher risk of ICU admission. Br J Anaesth 2020.

23. Wu C, Chen X, Cai Y, Xia Ja, Zhou X, Xu S, et al. Risk factors associated with acute respiratory distress syndrome and death in patients with coronavirus disease 2019 pneumonia in Wuhan, China. JAMA Internal Medicine 2020.

24. Guan WJ, Liang WH, Zhao Y, Liang HR, Chen ZS, Li YM, et al. Comorbidity and its impact on 1590 patients with COVID-19 in China: a nationwide analysis. Eur Respir I 2020;55(5):2000547.

25. Wan Y, Shang J, Graham R, Baric RS, Li F. Receptor recognition by the novel coronavirus from Wuhan: an analysis based on decade-long structural studies of SARS coronavirus. I Virol 2020;94(7):e00127-20.

26. Messerli FH, Siontis GCM, Rexhaj E. COVID-19 and renin angiotensin blockers: current evidence and recommendations. Circulation 2020.

27. Thum T. SARS-CoV-2 receptor ACE2 expression in the human heart: cause of a post-pandemic wave of heart failure? Eur Heart J 2020.

28. HFSA/ACC/AHA statement addresses concerns re: using RAAS antagonists in COVID-19 [Available from: https://www. acc.org/latest-in-cardiology/articles/2020/03/17/08/59/ hfsa-acc-aha-statement-addresses-concerns-re-using-raasantagonists-in-covid-19.

29. Liang WH, Guan WJ, Li CC, Li YM, Liang HR, Zhao Y, et al. Clinical characteristics and outcomes of hospitalised patients with COVID-19 treated in Hubei (epicenter) and outside Hubei (non-epicenter): A Nationwide Analysis of China. Eur Respir J 2020:2000562. 
30. Richardson S, Hirsch IS, Narasimhan M, Crawford IM, McGinn $T$, Davidson KW, et al. Presenting characteristics, comorbidities, and outcomes among 5700 patients hospitalized with COVID-19 in the New York city area. JAMA 2020.

31. Li B, Yang J, Zhao F, Zhi L, Wang X, Liu L, et al. Prevalence and impact of cardiovascular metabolic diseases on COVID-19 in China. Clin Res Cardiol 2020;109(5):531-8.

32. Arentz M, Yim E, Klaff L, Lokhandwala S, Riedo FX, Chong $M$, et al. Characteristics and outcomes of 21 critically ill patients with COVID-19 in Washington State. JAMA 2020;323(16):1612-4.

33. Zheng YY, Ma YT, Zhang JY, Xie X. COVID-19 and the cardiovascular system. Nat Rev Cardiol 2020;1 7(5):259-60.

34. Xie J, Tong Z, Guan X, Du B, Qiu H. Clinical characteristics of patients who died of coronavirus disease 2019 in China. JAMA Network Open 2020;3(4):e205619-e.

35. Epidemiology Working Group for NCIP Epidemic Response, Chinese Center for Disease Control and Prevention. The epidemiological characteristics of an outbreak of 2019 novel coronavirus diseases (COVID-19) in China. Zhonghua Liu Xing Bing Xue Za Zhi 2020;41(2):145-51.

36. Kang $Y$, Chen $T$, Mui $D$, Ferrari $V$, Jagasia $D$, Scherrer-Crosbie $M$, et al. Cardiovascular manifestations and treatment considerations in covid-19. Heart 2020.

37. Guo T, Fan Y, Chen M, Wu X, Zhang L, He T, et al. Cardiovascular implications of fatal outcomes of patients with coronavirus disease 2019 (COVID-19). JAMA Cardiology 2020.

38. Bhutani $M$, Hernandez $P$, Bourbeau J, Dechman $G$, Penz E, Aceron R, et al. KEY HIGHLIGHTS of the Canadian Thoracic Society's position statement on the optimization of chronic obstructive pulmonary disease management during the COVID-19 pandemic. Chest 2020.
39. Fu L, Wang B, Yuan $T$, Chen $X$, Ao $Y$, Fitzpatrick $T$, et al. Clinical characteristics of coronavirus disease 2019 (COVID-19) in China: a systematic review and meta-analysis. I Infect 2020:50163-4453(20)30170-5.

40. Niu S, Tian S, Lou J, Kang X, Zhang L, Lian H, et al. Clinical characteristics of older patients infected with COVID-19: a descriptive study. Arch Gerontol Geriatr 2020;89:104058.

41. Zhao Q, Meng $M$, Kumar R, Wu Y, Huang J, Lian $N$, et al. The impact of COPD and smoking history on the severity of Covid-19: a systemic review and meta-analysis. I Med Virol 2020.

42. Boccia S, Ricciardi W, loannidis JPA. What other countries can learn from Italy during the COVID-19 pandemic. JAMA Internal Medicine 2020.

43. Leung JM, Yang CX, Sin DD. COVID-19 and nicotine as a mediator of ACE-2. Eur Respir J 2020:2001261.

\section{Yazıșma Adresi/Address for Correspondence}

Prof. Dr. Gülay SAIN GÜVEN

Hacettepe Üniversitesi Tip Fakültesi, İc Hastalıkları Anabilim Dalı, Ankara-Türkiye

E-posta: gulay.sainguven@hacettepe.edu.tr 